\title{
低温焼結・導電性ペースト材料への応用に向けた 銅ナノ粒子の保護剂フリ一溶液合成 \\ Surfactant Free--solution Synthesis of Copper Nanoparticles for Low Temperature Sintering and Conductive Paste
}

\author{
川㠃 英也 ${ }^{*}$ ・大洞 康嗣* ・ 米澤 徹**・荒川 隆一 ${ }^{*}$
}

Hideya KAWASAKI, Yasushi OBORA, Toru YONEZAWA and Ryuichi ARAKAWA

\section{1.はじめに}

「プリンテッド・エレクトロニクス技術」とは，まるで 新聞や雑誌を刷るように，印刷により大量に高速に電子部 品や電子デバイスを製造する次世代の新技術であり，その 対象となる製品は極めて幅広い。現在, 主流となっている リソグラフィ技術とエッチング技術を用いて回路を形成す る方法では，大規模なスパッ夕装置や露光装置が必要とな り，高コスト化が問題となる。また，配線に用いない金属 部分を除去するためエッチングが必要となるが，この工程 に用いる大量のエッチング剤による環境負荷も問題視され ている。そのため電子機器の大幅なコストダウンができ, エッチングなどのウェットプロセスを使用しない環境配虑 型プロセスで微細配線が実現可能なプリンテッド・エレク トロニクス技術が注目を集めている。このプリンテッド・ エレクトロニクス技術が実現すれば，印刷技術を用いて連 続的な電子デバイスの製造が可能となることから，電子デ バイスのフレキシプル化や低コスト化，製造プロセスの低 温化により省エネルギーを実現する環境対応技術として, 薄膜ディスプレイ，電子ペーパー，有機 EL 照明などの製 造プロセスに劇的な变革をあたらすすのと期待されている。 この新技術を開拓するためには，インクとなる有機・無機・ 金属のナノ材料，高精度に制御された印刷技術，更に新た なデバイス設計・製造概念が必要であり，広範井で高度な 基盤技術形成が求められる。

\footnotetext{
* 関西大学化学生命工学部

吹田市山手町 3丁 3 番 35 号 $\overline{\text { T } 564-8680}$

Department of Chemistry and Materials Engineering,

Faculty of Chemistry, Materials and Bioengineering,

Kansai University

3-3-35 Yamate-cho, Suita-shi, Osaka, 564-8680, Japan ** 北海道大学大学院工学研究院

北海道札幌市北区北 13 条西 8 丁目 $\overline{\mathbf{T}} 060-8628$

Division of Materials Science and Engineering, Faculty of Engineering, Hokkaido University

Kita 13, Nishi 8, Kita-ku, Sapporo, Hokkaido 060-8628, Japan
}

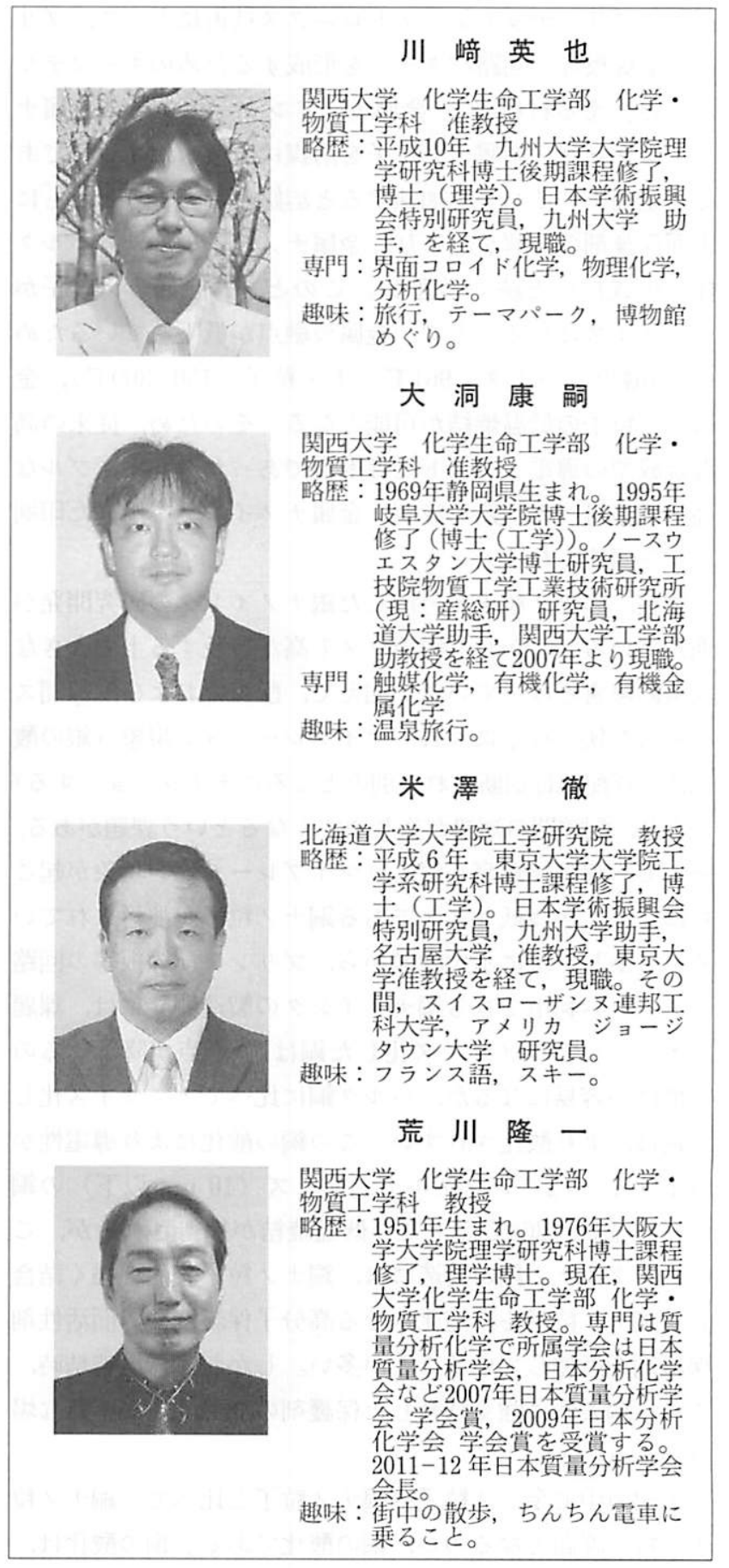


ナノインク… ナノインクとは、金属ナノ粒子を溶骺に分散させたインク

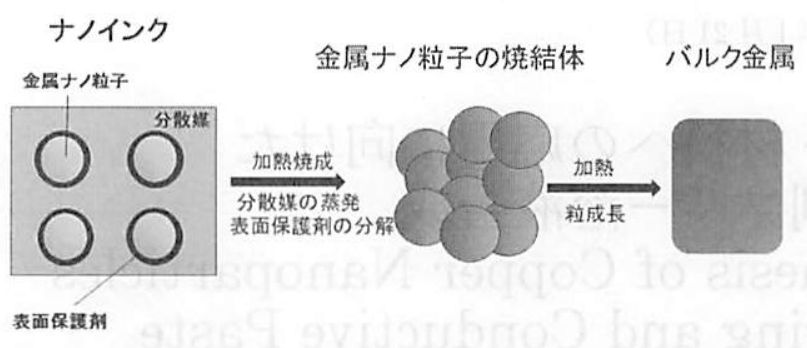

低温加熱によって、粒子間が金属接合を起こす(サイズ効果による骶点低下) 一高い熱·電気伝導性を有する導体形成、接合実装を低温で実現

図1 金属ナノインクにおける金属ナノ粒子の焼結過程

このプリンテッドェレクトロニクス技術にとって，プリ ント配線板等の回路パターンを形成するためのキーマテリ アルと言える材料が，“金属ナノインク”である。金属ナ ノインクとは, 金属ナノ粒子を溶媒に分散したインクであ る。金属ナノインクを加熱すると溶媒が蒸発するとともに 表面保護剂の分解が起こり，金属ナノ粒子の焼結，バルク 体への成長へと続く（図1）。このとき，金属ナノ粒子が ナノサイズになることで，金属の融点が低下しているため (銀の融点：バルク : $961^{\circ} \mathrm{C}$, ナノ粒子 : $150-300^{\circ} \mathrm{C}$ ), 金 属ナノ粒子の低温燒結が可能となる。そのため, 従来の高 温焼成型の導電ペーストでは困難であったフレキシブルな 高分子基材への回路形成が, 金属ナノインクを用いた印刷 により可能となる。

現在, 銀ナノ粒子を分散した銀ナノインクの研究開発が 進んでいる。しかし，銀のコスト高が普及する上で大きな 経済的障害となっている。加えて, 配線幅および配線間ス ペースが狭くなるにつれ, マイグレーション現象（銀の酸 化により配線は切断され, 別のところにデポジションする) により, 配線間の短絡が生じやすくなるという課題がある。 そこで, 導電性が高く銀よりマイグレーション現象が起こ りにくく，かつ低コストである銅ナノ粒子が注目されてい る。しかし, 次に示す課題から, プリント配線板等の回路 パターンへ利用できる銅ナノインクの製造開発には, 課題 が多い。（1）ナノサイズ化した銅は，融点が降下するの で焼結が容易になるが, バルク銅に比べてナノサイズ化し た銅は, より酸化されすい。この銅の酸化により導電性が 低下する。（2）シングルナノサイズ（10 nm 以下）の銅 ナノ粒子は, $200^{\circ} \mathrm{C}$ 以下での低温焼結が期待されるが, こ のシングルナノ銅の製造には, 銅ナノ粒子表面と強く結合 して銅ナノ粒子を安定化させる高分子保護剤や界面活性剂 保護剂を添加していることが多い。しかし，低温焼結時， これら銅表面に強く結合した保護剂の加熱除去が困難な場 合がある。

上記の中で金ナノ粒子や銀ナノ粒子と比べて, 銅ナノ粒 子で特に課題となるのが，銅の酸化である。銅の酸化は，
銅粒子の燒結温度の上昇と電気伝導性を低下させる点で好 ましくない。銅の酸化を抑制するため（銅粒子表面と空気 中との酸素との接触を最小限に抑制する), 銅ナノ粒子表 面を有機・無機保護剤でコートする必要がある。そのよう な表面保護剤・保護膜として, カーボン系保護膜, 界面活 性剤・高分子系の有機保護膜, シリカ系コート膜, 及び金 属系 (銀など) コート膜などがあげられる1)。

このような中, 著者らのグループは, 塩基性エチレング リコールを溶媒と還元剂として用いるポリオール法をべー スとしたシングルナノサイズの銅ナノ粒子の溶液合成法を 見出した ${ }^{2 \mathrm{a})}$ 。その特徵は, 約 $2 \mathrm{~nm}$ という極微小サイズで, かつナノ粒子間接合を妨害する有機保護剤（分散剤）を添 加せずに，銅ナノ粒子を合成できることにある。加えて， 本合成法で得られる銅ナノ粒子は酸化が抑制されており, $150^{\circ} \mathrm{C}$ の低温加熱によって銅粒子間が金属接合をおこす。 また最近, 著者らのグループでは, ジメチルホルムアミド (DMF) を溶媒と還元剤として用いる DMF 還元法をべー スとしたシングルナノサイズの銅ナノ粒子の溶液合成法も 見出した ${ }^{2 \mathrm{~b})}$ 。

本稿では, 著者らのグループで研究開発を進めている, これらシングルナノサイズ（約 $2 \mathrm{~nm} ）$ の銅ナノ粒子の製 造法とその特徴を中心に述べる。

\section{2. ポリオール法による金属ナノ粒子の合成}

金属ナノ粒子の合成方法は，1）気相法，2）液相法，3） 固相法に大別される。固相法は大きな粒子を粉砕して微粒 子をつくるが, 粉砕ではサブミクロン'(数百 $\mathrm{nm}$ ) 程度の 大きさが限界といわれている。近年, 液相法による銅ナ, 粒子の合成法が活発に報告されている ${ }^{324)}$ 。液相法の中で もポリオール法は, エチレングリコールなどの高沸点の多 価アルコール中で金属イオンを還元して金属ナノ粒子を得 る方法で，サイズの揃った金属ナノ粒子を大量に合成でき るといわれている。ポリオール法を用いることで, 金ナノ 粒子, 銀ナノ粒子, 及び銅ナノ粒子だけでなく, 白金, パ ラジゥム, コバルト, 鉄, ニッケルなど様々な金属におい て，金属ナノ粒子を合成できる。エチレングリコールを使 用するポリオール法では, エチレングリコールが溶媒と還 元剤の 2 つの働きをする。エチレングリコールを沸点近い 温度で加熱すると, エチレングリコールが酸化され，アル デヒドが生成し，そのアルデヒドにより金属イオンが還元 されると考えられている（式 1,2$) 。$

$$
\begin{aligned}
& \mathrm{HOCH}_{2} \mathrm{CH}_{2} \mathrm{OH} \rightarrow \mathrm{CH}_{3} \mathrm{CHO}+\mathrm{H}_{2} \mathrm{O} \\
& 2 / \mathrm{nM}^{\mathrm{n}+}+2 \mathrm{CH}_{3} \mathrm{CHO} \rightarrow \mathrm{CH}_{3} \mathrm{COCOCH}_{3}+2 / \mathrm{nM}+2 \mathrm{H}
\end{aligned}
$$

（1）式のエチレングルコールの酸化は, 塩基の存在で促進 されるといわれている。別の反応として, エチレングリコー 
ルの酸化物として（3）式に示すグリコールアルデヒドの 生成が提案されている。このグリコールアルデヒドが，金 属イオンを還元する。

$$
2 \mathrm{HOCH}_{2} \mathrm{CH}_{2} \mathrm{OH}+\mathrm{O}_{2} \rightarrow 2 \mathrm{HOCH}_{2} \mathrm{CHO}+2 \mathrm{H}_{2} \mathrm{O}(3)
$$

通常，ポリオール法では，金属ナノ粒子のサイズ制御と 分散安定性を保つために，ポリピリルピロリドン (PVP) などの高分子やセチルトリメチルアンモニウムブロマイド (CTAB) などの界面活性剤といった有機保護剤（分散剂） が添加される。また，金属イオンと分散剤とのモル比を変 えることにより，金属ナノ粒子のサイズや形態を変えるこ とができる。特に，金属ナノ粒子のある結晶面と有機保護 剂との間で, 結晶面特異的な相互作用がある場合, 結晶成 長速度がナノ粒子表面の各結晶面で異なることによって， キューブ，ワイヤー，シート状などの異方形状を有する金 属ナノ粒子が得られる。

ポリオール法を銅ナノ粒子に適用する大きな利点とし て，銅の酸化抑制があげられる。Larcher らは，200 Cの エチレングリコール（EG）中で，種々の金属酸化物が金 属に還元されるときの自由エネルギー変化 $\left(\Delta G_{\mathrm{red}}\right)$ を見 積むった ${ }^{25)} 。 \Delta \mathrm{G}_{\mathrm{red}}$ の值が負に大きいほど，金属酸化物が 金属に還元されやすい，つまり酸化されにくいということ になる。例えば, $\mathrm{Ag}_{2} \mathrm{O}$ の $\Delta \mathrm{G}_{\mathrm{red}}$ 值は, -270 - $300 \mathrm{kcal} /$ mol EGであり，EG を用いたポリオール法で銀ナノ粒子 が生成しやすいことがわかる。他方, $\mathrm{CeO}_{2}$ の $\Delta \mathrm{G}_{\mathrm{red}}$ 值は, +270 + $300 \mathrm{kcal} / \mathrm{mol} \mathrm{EG}$ で， Ce ナノ粒子を， EGを用 いたポリオール法で合成することは困難である。酸化銅 (I) の場合, $\mathrm{Cu}_{2} \mathrm{O} の \Delta \mathrm{G}_{\mathrm{red}}$ 值は $-70 \sim-100 \mathrm{kcal} / \mathrm{mol} \mathrm{EG}$ であり，EGを用いたポリオール法で生成した銅ナノ粒 子は，酸化が抑制されることになる。表 1 に，ポリオール
法を用いた銅ナノ粒子の合成について報告例をまとめた。

\section{3. 塩基ポリオール法によるシングルナノサイズの 銅ナノ粒子の合成}

我々はポリオールに塩基を添加した塩基ポリオール法と マイクロ波 (MW) 加熱を組み合わせることにより，シング ルナノサイズの銅ナノ粒子が合成できることを報告した ${ }^{2 \mathrm{a}) 。 ~}$ 本合成法では，保護剤を添加せずにシングルナノサイズ （約 $2 \mathrm{~nm}$ ）の銅ナノ粒子が合成できるのが特徴である （図 2)。以下にその合成の具体例を示す。

塩化銅（II）と $\mathrm{NaOH}$ をそれぞれ $\mathrm{EG} に$ に溶解して, $38 \mathrm{mM}$ 銅溶液と $0.5 \mathrm{M}$ 水酸化ナトリウム溶液を調製し, それぞれ $2 \mathrm{~mL}$ ずつ混合する。この溶液を， MW を用いて $300 \mathrm{~W}, 185^{\circ} \mathrm{C} て ゙ ， 0.5 \mathrm{~h}$ 加熱すると茶褐色の銅ナノ粒子分 散液が得られる。銅ナノ粒子を EG から分離するために, $1 \mathrm{M}$ 塩酸を加えて pH 3-4 に調整し，続いてジェチルエー

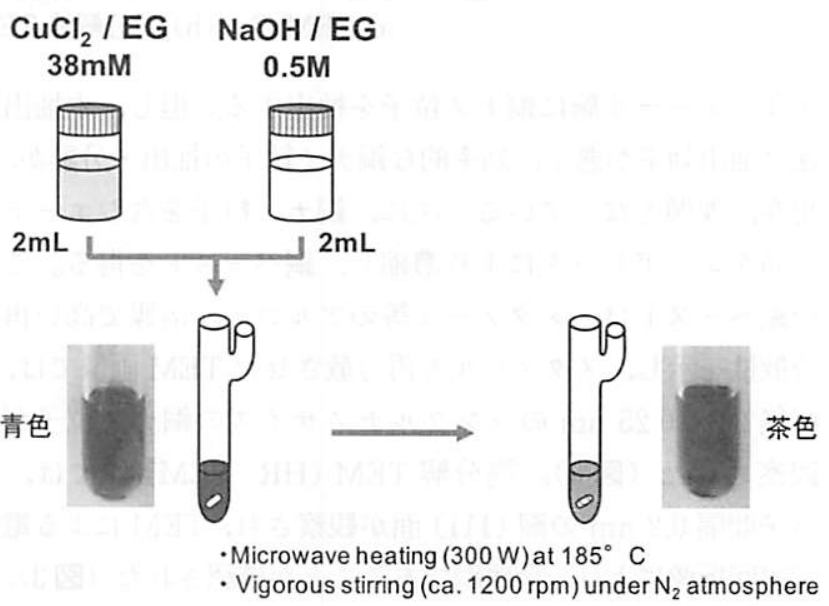

図 2 塩基ポリオール法によるシングルナノサイズの 銅ナノ粒子の合成

表 1 ポリオール法を用いた銅ナノ粒子の合成

\begin{tabular}{|c|c|c|c|c|c|c|}
\hline 溶媒 & 前駆体銅イオン & 還元剂 & 有機保護剂 & 粒子サイズ & 文献 & \\
\hline $\mathrm{EG}+\mathrm{NaOH}$ & $\mathrm{CuCl}_{2}$ & なし & なL & $2.3 \mathrm{~nm} \pm 0.3 \mathrm{~nm}$ & Kawasaki et al. Ref.[2a] & MW加熱 \\
\hline EG & $\mathrm{CuSO}_{4} \cdot 5 \mathrm{H}_{2} \mathrm{O}$ & $\mathrm{NaH}_{2} \mathrm{PO}_{2} \cdot \mathrm{H}_{2} \mathrm{O}$ & PVP(K30) & $10 \mathrm{~nm}$ & Zhu et al. Ref.[3] & MW加熱 \\
\hline $\mathrm{EG}+\mathrm{NaOH}$ & $\mathrm{CuSO}_{4} \cdot 5 \mathrm{H}_{2} \mathrm{O}$ & なし & なし & $200 \mathrm{~nm}$ (cube) & Sun et al. Ref.[4] & $2^{\circ} \mathrm{C} / \mathrm{min}$ で加熱 \\
\hline DEG & $\mathrm{CuSO}_{4} \cdot 5 \mathrm{H}_{2} \mathrm{O}$ & $\mathrm{NaH}_{2} \mathrm{PO}_{2} \cdot \mathrm{H}_{2} \mathrm{O}$ & $\operatorname{PVP}(M w=40 K)$ & $40-60 \mathrm{~nm}$ & Park et al. Ref.[5], [22] & \\
\hline 1,2-propane diol & $\mathrm{Cu}\left(\mathrm{CH}_{3} \mathrm{COO}\right)_{2} \cdot \mathrm{H} 2 \mathrm{O}$ & なし & なし & $100 \mathrm{~nm}-1 \mu \mathrm{m}$ & Anžlvar et al. Ref.[6] & \\
\hline $\begin{array}{l}\text { (EG, DEG, TEG, or BG) } \\
+\mathrm{NaOH}\end{array}$ & $\mathrm{Cu}(\mathrm{II}) \mathrm{X}\left(\mathrm{X}=\mathrm{OAc}^{-}, \mathrm{SO}_{4}{ }^{2-}, \mathrm{Cl}^{-}\right)$ & なし & なし & $50-200 \mathrm{~nm}$ & Carroll et al. Ref.[11] & \\
\hline DEG & $\mathrm{Cu}\left(\mathrm{CH}_{3} \mathrm{COO}\right)_{2} \cdot \mathrm{H} 2 \mathrm{O}$ & アスコルビン融 & PVP(K30) & $45-130 \mathrm{~nm}$ & Blosi et al. Ref.[12] & MW加熱 \\
\hline EG & $\mathrm{Cu}\left(\mathrm{CH}_{3} \mathrm{COO}\right)_{2} \cdot \mathrm{H} 2 \mathrm{O}$ & なし & $\operatorname{PVP}(M w=10 K)$ & $81 \pm 13 \mathrm{~nm}$ & Tsuji et al. Ref.[14] & Cu@Ag Core-Shell \\
\hline DEG & $\mathrm{CuSO}_{4} \cdot 5 \mathrm{H}_{2} \mathrm{O}$ & $\mathrm{NaH}_{2} \mathrm{PO}_{2} \cdot \mathrm{H}_{2} \mathrm{O}$ & $\operatorname{PVP}(\mathrm{K} 30)+\mathrm{CTAB}$ & $10 \mathrm{~nm}$ & Tang et al. Ref.[15] & \\
\hline $\mathrm{EG}+\mathrm{NaOH}$ & $\mathrm{CuSO}_{4} \cdot 5 \mathrm{H}_{2} \mathrm{O}$ & $\mathrm{NaBH}_{4}$ & $\operatorname{PVP}(M w=55 K)$ & $1.4-3.1 \mathrm{~nm}$ & Zhang, et al. Ref.[16] & \\
\hline $\mathrm{EG}+\mathrm{NaOH}$ & $\mathrm{CuO}$ & なし & な & $0.5-1 \mu \mathrm{m}$ & Fievet et al. Ref.[17] & \\
\hline DEG & $\mathrm{CuSO}_{4} \cdot 5 \mathrm{H}_{2} \mathrm{O}$ & $\mathrm{NaH}_{2} \mathrm{PO}_{2} \cdot \mathrm{H}_{2} \mathrm{O}$ & $\operatorname{PVP}(M w=10,29,44 \mathrm{~K})$ & $35,45,65 \mathrm{~nm}$ & Jeong et al. Ref.[18] & 酸化膜:3.1，2.5, $1.6 \mathrm{~nm}$ \\
\hline EG & $\mathrm{Cu}\left(\mathrm{CH}_{3} \mathrm{COO}\right)_{2} \cdot \mathrm{H} 2 \mathrm{O}$ & なし & なし & $30-50 \mathrm{~nm}$ & Okram et al. Ref.[19] & \\
\hline 1-heptanol+NaOH & $\mathrm{Cu}\left(\mathrm{CH}_{3} \mathrm{COO}\right)_{2} \cdot \mathrm{H} 2 \mathrm{O}$ & なし & oleylamine & $10 \mathrm{~nm}$ & Huaman et al. Ref.[20] & \\
\hline $\mathrm{EG}+\mathrm{NaOH}$ & $\mathrm{Cu}(\mathrm{II}) \mathrm{X}\left(\mathrm{X}=\mathrm{OAc}^{-}, \mathrm{SO}_{4}^{2-}, \mathrm{Cl}\right.$ & $\begin{array}{l}\mathrm{N}_{2} \mathrm{H}_{4} \cdot \mathrm{H} 2 \mathrm{O} \\
\mathrm{NaBH}_{4} \text {, or } \\
\mathrm{NaH}_{2} \mathrm{PO}_{2} \cdot \mathrm{H}_{2} \mathrm{O}\end{array}$ & $\begin{array}{l}\text { PVP }(M w=10 K, \\
40 K \\
55 K)\end{array}$ & $\begin{array}{l}5.0 \pm 0.5,9.6 \pm \\
1.0,13.7 \pm \\
1.8 \mathrm{~nm}\end{array}$ & Engels et al. Ref.[21] & $\begin{array}{l}5.0 \pm 0.5,9.6 \pm 1.0 \\
13.7 \pm 1.8 \mathrm{~nm}\end{array}$ \\
\hline $\mathrm{EG}+\mathrm{NaOH}$ & $\mathrm{CuSO}_{4} \cdot 5 \mathrm{H}_{2} \mathrm{O}$ & $\mathrm{N}_{2} \mathrm{H}_{4} \cdot \mathrm{H}_{2} \mathrm{O}$ & なし & $15 \mathrm{~nm}$ & Zhu et al. Ref.[23] & MW加熱 \\
\hline EG & $\mathrm{Cu}\left(\mathrm{CH}_{3} \mathrm{COO}\right)_{2} \cdot \mathrm{H} 2 \mathrm{O}$ & なし & なし & $100-120 \mathrm{~nm}$ & Zhao et al. Ref.[24] & MW加熱 \\
\hline
\end{tabular}

(ethylene glycol (EG), propyleneglycol (PG), diethylene glycol (DEG), tetraethylene glycol (TEG), and butylene glycol (BG) 

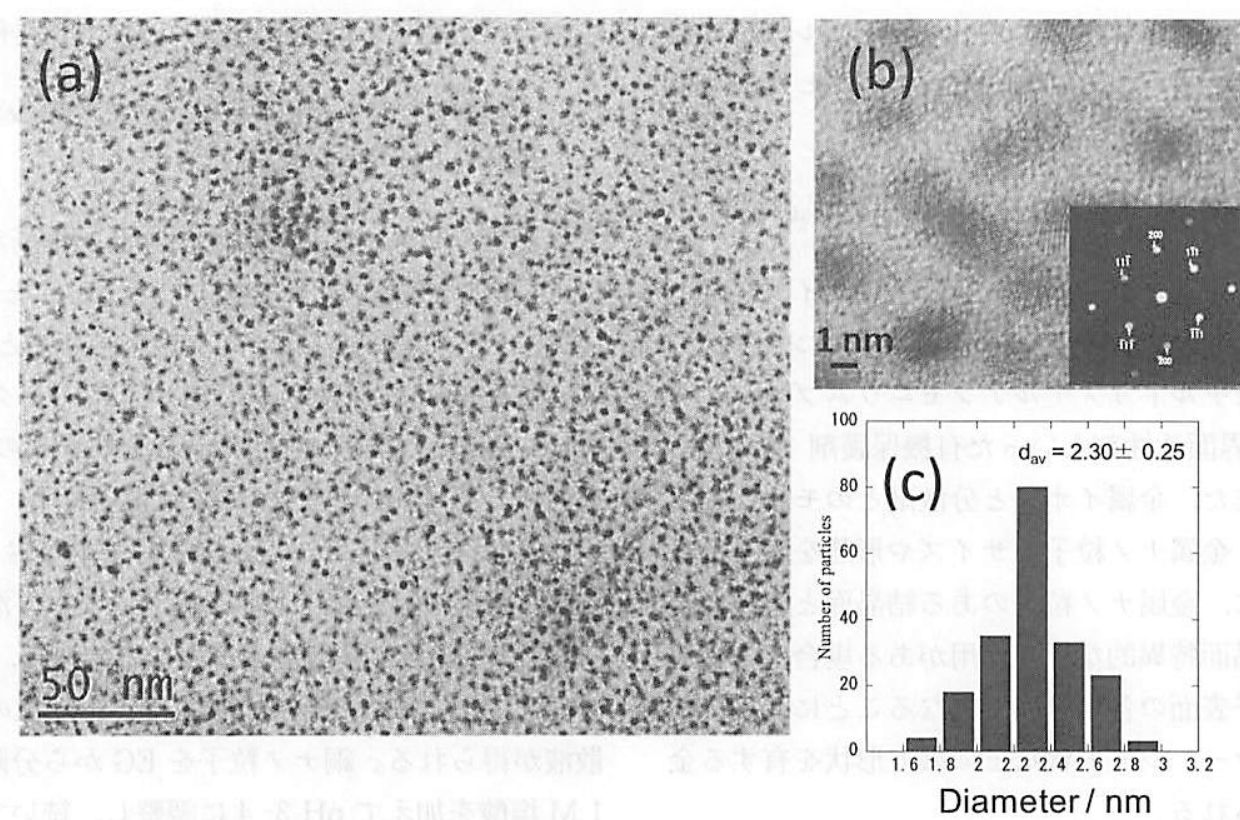

図 3 塩基ポリオール法により合成されたシングルナノサイズの銅ナノ粒子の (a) TEM 像, (b) 高分解能 TEM 像之電子線回折像, (c) 粒径分布

テルでエーテル層に銅ナノ粒子を抽出する。但し，本抽出 法は抽出効率が悪く，効率的な銅ナノ粒子の抽出・分離が, 現在，課題となっている。次に，銅ナノ粒子を含むェーテ ル層をエバポレータにより濃縮し，銅ペーストを得る。こ の銅ペーストは, メタノール等のアルコール溶媒で高い再 分散性を示し,メタノールで再分散させた TEM 画像では, 直径 $2.3 \pm 0.25 \mathrm{~nm}$ のシングルナノサイズの銅ナノ粒子が 観察された（図 3)。高分解 TEM (HR-TEM) 像では, 格子間隔 $0.2 \mathrm{~nm}$ の銅 (111) 面が観察され，TEMによる電 子線回折像により，金属銅であることが確認された（図 3)。 更に，本合成法で得られた銅ナノ粒子の酸化状態を，XPS （X 線光電子分光）と赤外吸収スペクトル（FT-IR）によ り検討した。その結果, 酸化銅に起因する試料ピークが観 測されなかったことから，銅ナノ粒子の酸化は抑制されて いることが支持された。

銅の表面酸化が進行すると, 酸化銅の生成に伴い銅ナ， 粒子分散液の色が変化する。本合成法で調製した銅ナノ粒 子は, 合成直後, 1 週間後, 3 週間後ともに, 銅ナノ粒子 の酸化に伴う紫外可視吸収 (UV-Vis) スペクトルに变化 がなかった（色变化がない）ことから,酸化による経時変 化も抑制されており，銅ナノ粒子の高い耐酸化性が示され た（図 4)。

マトリックス支援レーザー脱離イオン化質量分析 (MALDI-MS) により，銅ナノ粒子の表面分析を行った， その結果, ポリエチレングリコールのモノマー単位の分子 量に相当する $44 \mathrm{Da}$ 間隔のピーク群が，マススペクトル で観察されたことから，本方法で調製した銅ナノ粒子の表 面は溶媒由来のポリエチレングリコールのオリゴマー（分 子量 1500 程度）で被覆されていることが示唆された。こ

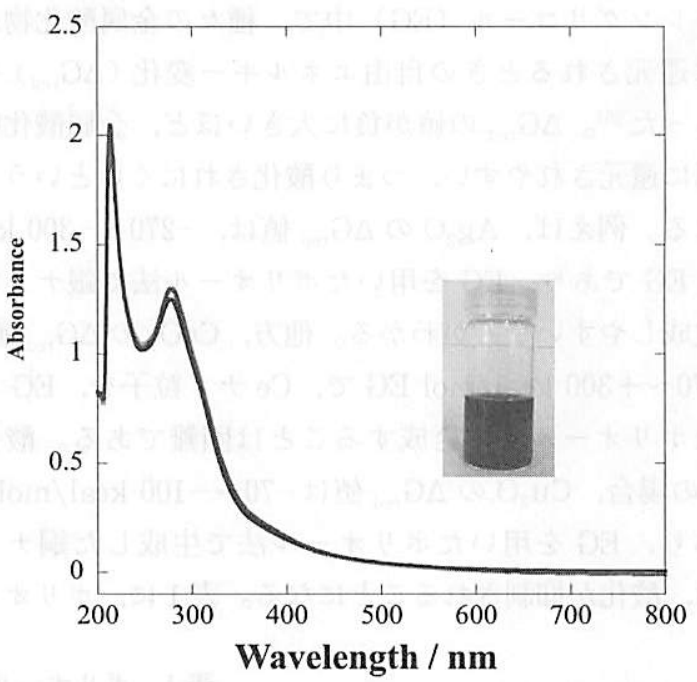

図 4 銅ナノ粒子のエチレングリコール分散液の紫外可視 吸収スペクトル。合成直後, 1 週間後, 3 週間後とも に，それぞれ 3 つのスペクトルが重なっており， 銅ナノ粒子の酸化に伴うスペクトル変化がなかった。

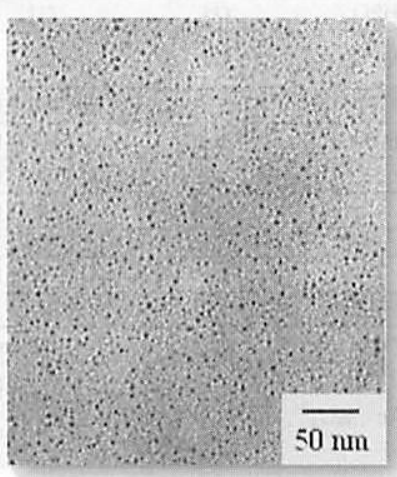

焼成前

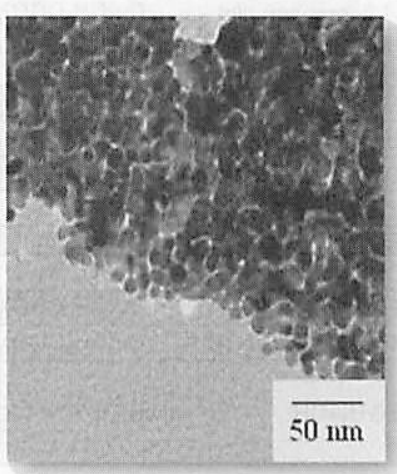

焼成後
図 5 銅ナノ粒子の燒結（減圧下で $150^{\circ} \mathrm{C}$ ) 
の銅ナノ粒子は, シングルナノサイズの特徴を生かして $150^{\circ} \mathrm{C}$ 程度の温度で低温焼結が起こることも観察された (図 5)。

マイクロ波は物質を高速かつ直接加熱できる特徴から電 子レンジに利用されているほか, 最近では, 有機化合物の 合成などへの応用研究が盛んに行われている。マイクロ波 加熱による金属ナノ粒子の本合成では, 溶液を均一かつ急 速に昇温させることができることから, 反応系内全体で同 時に多くの核を発生させることが可能となり（NaOH な どの塩基の存在む銅ナノ粒子の生成を促進する), 粒径が 小さくサイズの揃った金属ナノ粒子が生成したものと考え られる。また, 塩基性条件下, 高温下でエチレングリコー ルから生成したと考えられるポリエチレングリコールによ る保護膜, $\mathrm{OH}^{-}$イオン, 及び $\mathrm{EG}$ が銅ナノ粒子表面に吸 着し, マイクロ波加熱によって生成した銅ナノ粒子の核を 安定化することで, そのシングルナノサイズの銅ナノ粒子 と耐酸化性と分散安定性に寄与しているものと考えられる。

\section{DMF 還元法によるシングルナノサイズの銅ナノ 粒子の液相合成}

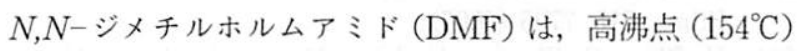
で，化学的/熱的安定性も高く，様々な物質を溶解するた め, 有機合成や無機合成のための反応溶媒として, 用いら れている。Liz-Marzánのグループをはじめとする多く のグループが, DMF 還元法による金属ナノ粒子の合成を 報告している ${ }^{26)}$ 。DMF 還元法による金属ナノ粒子の合成 では, DMF が溶媒および還元剤として作用するのが特徴 である。この DMF 還元法による金属イオンの還元能は, $100^{\circ} \mathrm{C}$ の上の温度で急激に増大する。その還元反応とし て, 以下の反応が提案されている。

$$
\begin{aligned}
& 3 \mathrm{HCONMe}_{2}+2 \mathrm{AuCl}_{4}^{-}+3 \mathrm{H}_{2} \mathrm{O} \\
& \rightarrow 2 \mathrm{Au}^{0}+3 \mathrm{Me}_{2} \mathrm{NCOOH}^{+} 6 \mathrm{H}^{+}+8 \mathrm{Cl}^{-}
\end{aligned}
$$

DMF の酸化によって生じるカルバミン酸 $\left(\mathrm{Me}_{2} \mathrm{NCOOH}\right)$ は, 不安定であるため, ジメチルアミン $\left(\mathrm{CH}_{3}\right)_{2} \mathrm{NH}$ と二 酸化炭素 $\mathrm{CO}_{2}$ に分解する。ポリオール法之同様に, DMF 還元法による金属ナノ粒子の合成においても，通常，金属 ナノ粒子のサイズ制御と分散安定性を保つために，ポリビ リルピロリドン (PVP) などの高分子やセチルトリメチル アンモニウムブロマイド (CTAB) などの界面活性剈といっ た分散剤が添加される ${ }^{26)}$ 。

我々は DMF 還元法により, 分散䬉の添加なしにシング ルナノサイズの銅ナノ粒子が合成できることを見出した ${ }^{2 \mathrm{~b})}$ 。 本合成法は, DMF 溶媒に塩化銅を加えて, オイルバス等 で $140^{\circ} \mathrm{C} に て$ 銅イオンを加熱還元する方法である。本合成 では，保護剤を添加せずにシングルナノサイズ（約 $2 \mathrm{~nm} ）$ の銅ナノ粒子が合成できるのが特徵である。なお，塩化銅
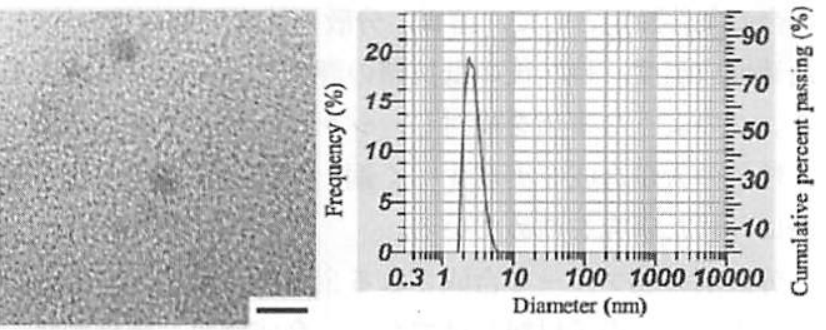

図 6 DMF 還元法により合成されたシングルナノサイズの 銅ナノ粒子の TEM 像（左）と DLSによる粒径分布 (右)。スケールバー : $2 \mathrm{~nm}$

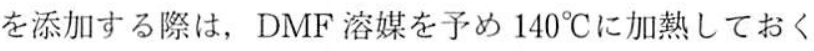
ことが重要である。以下にその合成の具体例を示す。

DMF 溶媒を予め $140^{\circ} \mathrm{C}$ に加熱しておく。塩化銅（II）を $0.1 \mathrm{mM}$ となるように加熱した DMF 溶媒に加えて, 8 時 間加熱する。その後, 減圧乾燥で DMF 溶媒を除去したも のをメタノールで再分散させたものの TEM 画像では, 直 径約 $2 \mathrm{~nm}$ の銅ナノ粒子が観察された。また, HR-TEM 像では, 格子間隔 $0.2 \mathrm{~nm}$ の銅 (111) 面が観察され金属銅 であることが確認された（図 6)。動的光散乱測定 (DLS) により, 平均粒径は, 約 2-3 $\mathrm{nm}$ と TEM 像との結果と 一致した。現在,この銅ナノ粒子は, ウルマンカップリン グ反応において, 高い触媒活性を示すことが見出されてい $3^{2 b)}$ 。しかし, 本合成法は $1 \mathrm{mM}$ 以下の希薄な銅イオン 濃度でしか銅ナノ粒子が合成できない（1 mM 以上だと大 部分が沈殿する)。つまり，希薄な銅イオン濃度が，シン グルナノサイズの銅粒子の生成条件として重要である。そ のため, 銅ナノ粒子が大量に必要とされる銅ナノインクへ の応用は実現しておらず, 今後の課題となっている。

\section{5. まとめ}

本報では, 分散剤を添加せずに合成されるシングルナ， サイズの銅ナノ粒子の合成法について, 塩基ポリオール法 と DMF 還元法を中心に紹介した。分散剤添加フリーでシ ングルナノサイズの銅ナノ粒子ということに焦点を当てた ため, 本報では, 高分子, カルボン酸やアミンを保護剂や 溶媒に用いた他の優れた銅ナノ粒子の合成法は紹介しなかっ た。塩基ポリオール法に基づく本合成法では, 約 $2 \mathrm{~nm}$ と いうシングルナノサイズでありながら, 銅ナノ粒子は酸化 が抑制されており， $150^{\circ} \mathrm{C}$ の低温加熱によって銅粒子間が 金属接合をおこす特徵を有している。DMF 還元法で合成 される約 $2 \mathrm{~nm}$ の銅ナノ粒子では, DMF 溶媒の沸点がエ チレングルコールに比べると低いことから, 溶媒除去が比 較的容易である。但し, 現時点では, 塩基ポリオール法と DMF 還元法で得られるシングルナノサイズの銅ナノ粒子 の大量合成は夹現していない。そのため今後は, 本合成法 のスケールアップに向けた最適化を行うことが重要な課題 となっている。また，ナノインク材料として適用していく 
場合の条件設定として, 溶媒, 分散・粘度調製剂等の検討, 最適焼成温度，焼結後の抵抗值の評価などを行う必要があ る。このような事項を検討し，シングルナノサイズの銅ナ ノ粒子の大量合成を実現すべく銅ナノインクの実用化を視 野に入れた研究を進めている。

分散剂添加フリーで合成される金属ナノ粒子は，その特 徵を生かし, 電子材料だけでなく, 合成触媒, 電極触媒, 金属ナノ粒子を用いた高感度センシングなど他の分野での 応用の屯期待される27)。

\section{謝辞}

本文は，株式会社 AndTech 出版「導電性ペースト／イ ンク」の内容を改变したものです。AndTech 青木様に感 謝いたします。

\section{参 考 文 献}

1) S. Magdassi, M. Grouchko, A. Kamyshny, Materials, 3 , $4626(2010)$.

2) a) H. Kawasaki, Y. Kosaka, Y. Myoujin, T. Narushima, T. Yonezawa, R. Arakawa, Chem. Commun., 47, 7740 (2011). b) Y. Isomura, T. Narushima, H. Kawasaki, Y. Yonezawa, Y. Obora, Chem. Commun., 48, 3784 (2012).

3) H. T. Zhu, C. Y. Zhang, Y. S. Yin, J. Cryst. Growth, 270, $722(2004)$.

4) J.Sun, Y. Jing, Y. Jia, M. Tillard, C. Belin, Mater. Lett., 59, 3933 (2005).

5) B. K. Park, S. Jeong, D. Kim, J. Moon, S. Lim , J. S. Kim, J. Colloid Interface Sci., 311, 417 (2007).

6) A. Anžlvar, Z. C. Orel, M. Žigon, J. Eur. Ceram. Soc., 27, 987 (2007).

7) T. Yonezawa, N. Nishida, A. Hyono, Chem. Lett., 39, 548 (2010).
8) P. Huang, J. Lin, Z. Li, H. Hu, K. Wang, G. Gao, R. He, D. Cui, Chem. Commun., 46, 4800 (2010).

9) Y. Wang and T. Asefa, Langmuir, 26, 7469 (2010).

10) K. P. Rice, E. J. Walker Jr., M. P. Stoykovich, A. E. Saunders, J. Phys. Chem. C, 115, 1793 (2011).

11) K. J. Carroll, J. U. Reveles, M. D. Schultz, S. N. Khanna, E. E. Carpenter, J. Phys. Chem. C, 115, 2656 (2011).

12) M. Blosi, S. Albonetti, M. Dondi, C. Martelli, G. Baldi, J. Nanopart. Res., 13, 127 (2011).

13) M. Tsuji, M. Hashimoto, Y. Nishizawa, M. Kubokawa, T. Tsuji, Chem. Eur. J., 11, 440 (2005).

14) M. Tsuji, S. Hikino, Y. Sano, M. Horigome, Chem. Lett., 38, 518 (2009).

15) X. F Tang, Z. G Yang, W. J Wang, Colloids Surf. A, 360, 99 (2010).

16) H. X. Zhang, U. Siegert, R. Liu, W. B. Cai, Nanoscale Res. Lett., 4, 705 (2009).

17) F. Fievet, F. Fievet-Vincent, J. P. Lagier, B. Dumont, M. Figlarz, J. Mater. Chem., 3, 627 (1993).

18) S. Jeong, K. Woo, D. Kim, S. Lim, J. S. Kim, H. Shin, Y. Xia, J. Moon. Adv. Funct. Mater., 18, 679 (2008).

19) G. S. Okram, N. Kaurav, J. Appl. Phys., 110, 023713 (2011)

20) J. L. C. Huaman, K. Sato, S. Kurita, T. Matsumoto, B. Jeyadevan, J. Mater. Chem., 21, 7062 (2011).

21) V. Engels, F. Benaskar, D. A. Jefferson, B. F. G. Johnson, A. E. H. Wheatley, Dalton Transactions, 39, 6496 (2010).

22） B. Park, D. Kim, S. Jeong, J. Moon, J. S. Kim, Thin Solid Films, 515, 7706 (2007).

23) H. Zhu, C. Zhang, Y. Yin, Nanotechnology, 16, 3079 (2005).

24) Y. Zhao, J. J. Zhu, J. M. Hong, N. Bian, H.Y. Chen, Eur. J. Inorg. Chem., 4072 (2004).

25) D. Larcher, R.Patrice, Journal of Solid State Chemistry, 154, 405 (2000).

26) I. Pastoriza-Santos, L. M. Liz-Marza 'n, Adv. Funct. Mater., 19, 679-688 (2009).

27) H Kawasaki, Nanotechnol Rev., DOI 10.1515/ntrev-20120079. 